\author{
Anna Świrska ${ }^{1}$ \\ Siedlce University of Natural Sciences and Humanities, Poland
}

Lina Marcinkevičiūtè, Jan Žukovskis

Aleksandras Stulginskis University, Lithuania

\title{
MANAGEMENT OF NATURAL RESOURCES WITH AIM SUSTAINABLE RURAL DEVELOPMENT: COMPARATIVE ANALYSIS OF THE CASE OF THE LITHUANIAN ELDERSHIP AND POLISH MUNICIPALITY
}

The article analyzes sustainable rural development as development of rural localities that promotes progressive and effective management of resources, in coordination of their protection and sustainable usage with regard to requirements set in different areas (economics, social development, culture, law and environmental protection). The natural resources' sorts, functions and indicators related to usage of natural resources are described. The strengths and weaknesses of environmental changes, the solution possibilities of the sorest problems and probable threats are named. The essential attention is given to the main components of the environment - air, water, climate, landscape, and problems of biological diversity.

The article stresses the sustainable development of natural resources through strategic usage of natural resources that is beneficial to rural localities and residents. The described research was carried out in Zasliai eldership of Kaisiadorys region (Lithuania) and in Siedlce Municipality of Siedlce Poviat (Poland). The condition of its natural resources, management tools and significance for sustainable development of the locality were assessed. The improvement directions of management of natural resources in the eldership were named and substantiated with regard to the components of sustainable development (economic, environmental protection and social-cultural).

Keywords: management of natural resources, management of resources based on community needs, sustainable rural development.

\section{Introduction}

The rural development and applicable tools affect the condition and functionality of the resources present in the locality. Besides, their rational usage affects the expansion of other sectors of economic activities (Aleksandravičius, ir kt., 2011). The management of rural natural resources is a complex process that integrates various rural resources in order to create common potential of the locality's development. The integrated resources and their direct and indirect influence of management on other sectors may be regarded as the result of joint activity - synergy. The synergetic effect creates evident input in development of the locality's potential, creation of added value not only in the aspect of development of local production and economic activities, but also with regard to creation of image, increase of attractiveness and attraction of investments (Baležentis, 2011). The

${ }^{1}$ Faculty of Economic and Legal Sciences 
perception of local potential on the ground of the analysis of resources determines the diversity of possibilities and solution methods of problems. The abundance of available resources, their quality or significance for the locality are not the only factors, which affect rural development; it is also affected by support of authorities, investments to facilities, marketing tools and managerial decisions. The financial support has been and is an important tool used to protect natural resources of each country in the course of development of competitiveness of rural localities through various economic activities. The management of natural resources should be based on the desire of the interested parties to identify the environmental problems and to find their possible solution methods. The object of research is management of natural resources. The purpose of research is to identify and substantiate the improvement directions of management of natural resources. Tasks of research: to analyze the principles of management of natural resources and sustainable development in the theoretical aspect, to carry out assessment of condition of natural resources in the eldership; and to prepare recommendations for management of natural resources in the eldership. Research methods: analysis of scientific literature, analysis of documents, comparative analysis, and structural interview.

\section{Theoretical aspects of management of natural resources in pursuit of sustainable rural development}

It should be noted that sustainable management of natural resources is a part of harmonious (economic, environmental and social) rural development, thus only the natural resources, which are used correctly, strategically and optimally could be of benefit for rural localities and their residents. According to the data of scientific research (Benoit; Charles, 2012), sustainable usage of local resources allows protecting natural resources and resources created by humans in various localities, to provide the topquality products, and to integrate this for behalf of the region. In order to use the local natural resources as effectively as possible, it is necessary to give more attention to planning of local facilities and control of resources' usage. According to Grundey (2012), the management actions, which are properly planned, applied and controlled, can have only positive impact; however, it is necessary to follow the main management principles of natural resources: effectiveness (few disputes and few efforts to maintain organizational order); stability (ability "to accept" programme changes, investments to new technologies); resistance (ability to react properly to surprises and sudden external hindrances); and fairness (transparency of activity). According to Grant (2010), when the external environment is changing continually, the internal resources have to serve as much more stable ground, on the basis of which the development strategy is formed. The analysis of the local resources allows assessing the condition of local resources and their significance on the level of community, eldership and municipality.

According to European Commission guidelines "Europe 2020" strategy on the rational management of resources includes three correlated priorities (Communication From The European Commission Europe 2020. A European strategy for smart, sustainable and inclusive growth $\operatorname{COM}(2010)$ 2020, Burchart-Korol, 2016, p.52):

- intelligent development - development of a knowledge-based economy and innovation, 
- $\quad$ sustainable development - promoting a resource-efficient, ecological and more competitive economy,

- $\quad$ inclusive growth - supporting an economy of high level of employment, ensuring social and territorial cohesion.

When the strengths and weaknesses of environment quality changes, the solution possibilities of the sorest problems and probable threats were analyzed in the article, the major attention was given to the main environmental components - air, water, climate, landscape, and problems of biological diversity. With regard to the data of the analysis of scientific literature (Herriges; Kling, 2012; Krankalis; Anzelyte, 2013), the natural resources were divided into 7 sorts: sun, ambient air and climate, water, landscape, resources of live nature and minerals.

It should be noted that all the sorts of natural resources are vital for human life and welfare: the supply functions are used to provide such resources as food, water, wood and fibre, the regulatory functions are used to control climate and amount of precipitation, water (e.g., floods), waste and spread of diseases. The cultural functions cover beauty, inspiration and rest, which contributes to spiritual welfare; the auxiliary functions cover soil's formation process, photosynthesis and cycle of nutritional elements, which serve as a ground for growing and production ((Bukantis, Gedžiūnas ir kt., 2008).

It may be presumed (Dargužas, 2011; Kisielienè, 2012; Skurdeniené; Šeškauskaitè, 2010) that the publicly active residents tend to protect environment more; they take part in the events of environment-cleaning; and that business is also induced (for example, when certain economic branches (tourism, services, high technologies) are developed, the negative impact on environment is smaller than in case of development of traditional industry). As noticed by (Lynam; Norfolk, 2013; Mont; Bleischwitz, 2012), the management of natural resources based on community needs is integral to the strategy of local development; when the tasks of resources' management are set and implemented successfully, the local environment protection processes and satisfaction of the residents are improving; however, it is necessary to identify the performance indexes, which could help to measure the implementation degree of these tasks.

\section{Practical aspects of management of natural resources in pursuit of sustainable rural development: comparative analysis and assessment of condition of natural resources}

One of the key factors contributing to sustainable rural development are local governments and decentralized administration system. The importance of localities (municipalities in Poland and elderships in Lithuania) become very evident in the course of planning process, i.e. when long-term strategic plans, which serve as a ground for sustainable development, are prepared. These authorities are within the closest distance to the residents, business, schools, non-governmental organizations, so they can look deeper to current problems, to foresee the results of the projects, and to use the available resources optimally. It is especially important to understand what sustainability means in particular situation at particular time, how much it could be related to pursuing the goals of local development, and how much it is related to the protection of natural resources. When the rural localities are developed, the principles of preserving management of 
natural resources would be followed. It should be induced to pollute, to use the local natural resources more effectively, to invest into new technologies, and to create new products or services in observance of ecologic principles.

The research of the article's authors was carried out in Zasliai eldership in Kaisiadorys region as well as in Siedlce municipality in order to determine the condition of natural resources, management tools and significance for sustainable development of the locality. The following was carried out: analysis of management of natural resources in the eldership and assessment of condition of natural resources; the significant factors of resources' management were identified and their relations with the performance results were determined. The first stage of research, the analysis of documents, allowed making logical conclusions on the ground of essence of the analyzed material (analysis of the document's content was carried out). The second stage of research, comparative analysis, was used to identify the areas of activity in need of improvement and the methods, how to adapt successful experience or examples of success. This method was applied in order to determine the advantages of local natural resources and their usage possibilities in order to identify the management tools of resources and components of sustainable development, which could be used to achieve sustainable rural development. The third stage of research was structured interview. The particular questions and their sequence were determined. The competent specialists with long professional experience, who could provide the most reliable and comprehensive information about local natural resources and their management were interviewed. It was attempted to learn the most relevant problems of management and usage of natural resources.

Analysis of condition of natural resources.

Soil: The soil in the eldership is very versatile. The large part of soil is turfy and podsolic soil. 88,34 percent of soil are of low and very low nitrogen content. The soils of high and very high nitrogen content make 11,66 percent. The land in the territory is much tamed. The landed property of various purposes occupies 68 percent of the eldership's area. Among all the land farmland, the arable takes 56,7 percent, gardens 1 percent, pastures and meadows take 23,8 percent, the roads and protection zones take 5,5 percent of the eldership's territory, and other lands - 13 percent. (Study of Application of Advanced Technologies and Good Practice in Agriculture, 2013). Analysis of Siedlce municipality shows that soil condition seems to be less fertile and varied. Gmina Siedlce is an rural municipality, where the arable land covers 6724 ha, pasture meadows 2497 ha, orchards 154 ha. Light soil, classes IV, V, VI predominate. They determine to a large extent the character of agricultural production dominated by rye, triticale, oat and potatoes. The municipality is a significant resource base in the production of vegetables, fruits and mushrooms. Meadows and pastures create conditions for the production of milk and beef cattle (www.gminasiedlce.pl).

Solar energy: It would be the most effective to use the solar energy to heat water. The turnover of the sun's shine is sufficient in order to use effectively the solar collectors of small area. In order to satisfy the needs of warm water for individual house, some $20 \mathrm{~m}^{2}$ collectors should be installed, while the block of flats would need approximately $60 \mathrm{~m}^{2}$. The usage of solar and geothermal energy in the eldership is only 0,6 percent. According to the study of possibilities to supply rural localities with thermal energy, only less than 0,5 percent of individual houses have thermal pumps to hear their housing and prepare ho water, while the solar energy is used only by individual persons. 
Ambient air: The cars and special servicing transport are used in the territory of both local units.. In total 18920 vehicles were registered in 2016/2017 in Zasliai eldership. The interstate railway is nearby. For the inhabitants of Siedlce municipality the main role is the road system. Through the municipality there are several major communication routes with high traffic intensity. The most important one is the WarsawTerespol national road, the A-2 motorway (in near future). These trails affect the deterioration of air and acoustic environment. Overall, the climate and health conditions in the study area can be described as average. The most unfavorable for housing in terms of the climate are the valleys and lower parts of landscape. The priority in the plan to improve quality of ambient air is given to cleaning and irrigation of streets and roadsides, control of construction sites and servicing transport, planting of problematic land areas, execution and control of valid environmental normative documents. As energy resources are getting more and more expensive, the power production of small wind power stations is developed rapidly. It has become accessible to many households. The special plan of layout of wind power stations in the municipal territory provides expansion of the network of wind power stations in the eldership, too. The general plan was created, where it is planned to arrange small wind power stations up to $250 \mathrm{~kW}$ in the eldership.

Water: The water ponds and protected territories around them can be distinguished as the most significant natural resources in the eldership. The preservation of these resources and development of sustainable expansion principles could bring economic benefit to the eldership. It may be presumed that the group of resources is quite significant on the local level. The abundance of lakes attracts urban residents; however the underdeveloped sector of public services is not able to attract bigger flows of tourists. The waters in the territory consist of the rivers, streams, lakes, ponds, water reservoirs, channels, trenches, and meres. The waters occupy about 1,9 percent of the total territory. Siedlce municipality is located in the Bug River basin. It is dewatered by Liwiec River and its tributaries: Muchawa and Helenka. These rivers are characterized by significant fluctuations in water levels. These rivers are not well developed in terms of tourism. The largest reservoirs of surface waters are fishponds in Golice and Stara Wieś and the "Muchawka" retention reservoir on the Muchawa river. This reservoir is located within the city of Siedlce, but in the immediate neighbourhood of Siedlce municipality.

Landscape: The eldership is characterized by hilly landscape. The "European forest" has been planted. The ferry over the Neris is reached if you turn to the direction of Ciobiskis from Zasliai - it is almost unique in Lithuania. The area of Siedlce municipality is characterized by a rather monotonous landscape. A flat or undulating (with slopes not exceeding 5\%) form covers large areas both in the west and east part of municipality. There are dunes (in the south-west) and sandy fields in the municipality.

Resources of live nature: The animals and plants of taiga and broad-leaved forests are characteristic to the eldership. The broad-leaved forests and spruce woods with the elements of broad-leaved forests are predominant. The forests occupy 18,6 percent. The forestry owns 644,5 ha of the land of forest purpose. The agricultural forests occupy 1074 ha area, and the nurseries of non-forest fund occupy 109 ha. There are 5 reserves of local significance, 1 national landscape reserve ad 4 natural monuments of local significance. The protected territories occupy approximately 375 ha. Siedlce 
municipality is characterized by low forest cover. Only $9.7 \%$ of the total area of the municipality is covered by forests. Due to the distance of up to $10 \mathrm{~km}$ from the administrative borders of Siedlce city (over 80 thousand inhabitants) all forests in the municipality are environmentally protected. The total forest area is 1,460 , whereas the majority ( $811 \mathrm{ha}$ ) belongs to private owners. Siedlce municipality belongs to areas of high natural values. The 1992 nature inventory of the municipality revealed 16 localities areas of very high natural and landscape values. The Liwiec Valley, including the Siedlce ponds, has been designated as a national park of national importance, and fragments of the Muchawa valley and the Chodow forest as - regional. Some parts of the municipality: 27431.5 ha are covered by Natura 2000 programme. It is an area of Liwiec Valley (CODE: PLB140002) of special protection for birds (according to Birds Directive).

Minerals: The minerals in the eldership are sand, gravel, clay and peat. The sands and gravels occupy 5,1 ha in the eldership and the quarries $-5,2$ ha. Gravel and sand are mainly used to make building materials, while the peat is used to make compost (to improve soil), to make pots for sprout growing, and packing materials. The minerals in Siedlce municipality are gravel and sand. There are 3 documented reserves of mineral resources, two have been already emptied and one - active. (Szuflicki (ed.) Bilans zasobów złóż kopalin, 2016).

In order to present the opportunities for natural resourses management in Siedlce Municipality, the SWOT analysis was conducted. Some its resuls are presented below in table 1 .

Table 1. SWOT analysis of Siedlce Municipality

\begin{tabular}{|c|c|}
\hline \multicolumn{2}{|c|}{ SWOT Analysis of Natural Resources of Siedlce Municipality } \\
\hline \multicolumn{2}{|l|}{ Geographic location, area, population } \\
\hline Strengths & Weaknesses \\
\hline $\begin{array}{l}\text { Favorable location with close distance to } \\
\text { Siedlce City } \\
\text { National, provincial, district Road } \\
\text { Well-developed technical infrastructure } \\
\text { The course of the railway line } \\
\text { Expanded suburban communications }\end{array}$ & $\begin{array}{l}\text { The aging community of the } \\
\text { municipality No crèches } \\
\text { The fragmented settlement network } \\
\text { The need to change the development } \\
\text { plan }\end{array}$ \\
\hline Opportunities & Threats \\
\hline $\begin{array}{l}\text { The dynamic development of the neighboring } \\
\text { city } \\
\text { Migration of the city's inhabitants to the } \\
\text { municipality } \\
\text { High sense of security }\end{array}$ & $\begin{array}{l}\text { Keeping the trend of low reproduction } \\
\text { of the population }\end{array}$ \\
\hline \multicolumn{2}{|l|}{ The natural environment } \\
\hline Strengths & Weaknesses \\
\hline $\begin{array}{l}\text { Good condition of the commune forest } \\
\text { Good value dining facilities } \\
\text { Successive replacement of asbestos roof }\end{array}$ & $\begin{array}{l}\text { Poorly developed tourist } \\
\text { infrastructure } \\
\text { Poor promotion of natural and }\end{array}$ \\
\hline
\end{tabular}




\begin{tabular}{|c|c|}
\hline $\begin{array}{l}\text { coverings co-financed by environmental funds } \\
\text { Placing in the area of the community valuable } \\
\text { natural areas - such as nature reserves } \\
\text { High rate of waste segregation }\end{array}$ & $\begin{array}{l}\text { landscape values } \\
\text { Undeveloped water reservoiurs } \\
\text { (rivers) } \\
\text { The lack of a developed network of } \\
\text { agritourism services } \\
\text { High energy consumption of public } \\
\text { buildings }\end{array}$ \\
\hline Opportunities & Threats \\
\hline $\begin{array}{l}\text { Increasing interest of the inhabitants of the city } \\
\text { settle in the municipality } \\
\text { Opportunity to develop agritourism, rural } \\
\text { tourism and recreation (bicycle paths) } \\
\text { Possibility of obtaining EU subsidies for } \\
\text { environmental and waste management projects } \\
\text { Increasing demand for leisure and } \\
\text { entertainment services } \\
\text { Fashion for healthy food and healthy lifestyle } \\
\text { Increased interest in renewable energy sources } \\
\text { Demand for agriculture products }\end{array}$ & $\begin{array}{l}\text { Low ecological awareness } \\
\text { Rapidly growing production costs in } \\
\text { agriculture }\end{array}$ \\
\hline \multicolumn{2}{|l|}{ Social sphere } \\
\hline ths & Weaknesses \\
\hline $\begin{array}{l}\text { Good location of social infrastructure (schools, } \\
\text { day centers, village clubs) } \\
\text { Well-functioning } \\
\text { organizations } \\
\text { Cyclical organization of cultural and sport } \\
\text { events (harvest fest, festivals, contests, } \\
\text { competitions, integration events) }\end{array}$ & $\begin{array}{l}\text { Insufficient number of kindergartens } \\
\text { and crèches, and too few schools in } \\
\text { relation to the number of students } \\
\text { Poor integration of residents } \\
\text { Unused potential of rural daycare } \\
\text { centers as meeting places and } \\
\text { integration of residents } \\
\text { Educational staff living out of } \\
\text { Municipality with less contact with } \\
\text { municipal citizens } \\
\text { Lack of local cultural leaders } \\
\text { Limited access to specialized medical } \\
\text { services }\end{array}$ \\
\hline Opportunities & Threats \\
\hline $\begin{array}{l}\text { Possibility of using EU funds for the } \\
\text { development of the social sphere } \\
\text { Adopting cultural, educational and educational } \\
\text { facilities, conferences, opportunities for greater } \\
\text { integration and awareness of the inhabitants } \\
\text { Streamlining the cooperation between the } \\
\text { administration and non-governmental } \\
\text { organizations and promoting bottom-up }\end{array}$ & $\begin{array}{l}\text { Poor cultivating of subregion } \\
\text { traditions } \\
\text { Inadequate budgetary resources for } \\
\text { cultural and sport activities } \\
\text { Failure of national identity } \\
\text { High cost of education } \\
\text { Complicated procedures for acquiring } \\
\text { and settling funds for the }\end{array}$ \\
\hline
\end{tabular}


\begin{tabular}{|l|l|} 
initiatives. & development of culture activities \\
\hline
\end{tabular} Source: Strategy of Siedlce Municipality Development

Based on the information presented in the table, it is possible to present the directions of changes and improvements in the management of the development and natural resources of the municipality.

It is possible to state that upon identification of competitive advantages of the locality and assessment of the available resources, it is possible to determine the tools, how to reinforce the locality's competitiveness without prejudice to the principles of sustainable rural development.

\section{Improvement of management of natural resources in the eldership}

Following the data of theoretical analysis and practical researches, the directions of improvement of management of natural resources in the eldership were identified and substantiated in accordance with the components of sustainable development (economic, environmental protection and social-cultural), and the practical recommendations for actors of local development were prepared (Table 2).

Table 2. Directions of improvement of management of natural resources in the eldership in accordance with the components of sustainable development

\begin{tabular}{|c|c|c|c|c|}
\hline \multirow[t]{2}{*}{$\begin{array}{l}\text { Improvement } \\
\text { direction }\end{array}$} & \multicolumn{3}{|c|}{$\begin{array}{l}\text { Planned results in accordance with component } \\
\text { of sustainable development }\end{array}$} & \multirow[t]{3}{*}{$\begin{array}{l}\text { Actors of local } \\
\text { development }\end{array}$} \\
\hline & Economic & $\begin{array}{l}\text { Environmenta } \\
\text { l protection }\end{array}$ & Social-cultural & \\
\hline \multirow{3}{*}{$\begin{array}{l}\text { Improvement } \\
\text { of quality of } \\
\text { soil and } \\
\text { bioproductio } \\
n \text { farm }\end{array}$} & \multicolumn{3}{|c|}{$\begin{array}{l}\text { Planting of infertile territories or territories les } \\
\text { favourable for farming with forest }\end{array}$} & \\
\hline & $\begin{array}{l}\text { The owners of } \\
\text { private land } \\
\text { could plant } \\
\text { infertile } \\
\text { territories or } \\
\text { territories less } \\
\text { favourable for } \\
\text { farming with } \\
\text { forest. It is } \\
\text { recommended } \\
\text { to acquire trees } \\
\text { from Zasliai } \\
\text { forestry that } \\
\text { manages forest } \\
\text { resources in } \\
\text { the eldership }\end{array}$ & $\begin{array}{l}\text { The growing } \\
\text { forest areas } \\
\text { would } \\
\text { change the } \\
\text { eldership's } \\
\text { landscape, } \\
\text { improve } \\
\text { ecologic } \\
\text { conditions } \\
\text { and would } \\
\text { contribute to } \\
\text { reduction of } \\
\text { climate } \\
\text { changes }\end{array}$ & $\begin{array}{l}\text { The work } \\
\text { places would } \\
\text { be created } \\
\text { for persons } \\
\text { receiving } \\
\text { municipal } \\
\text { allowances, } \\
\text { and the } \\
\text { activities of } \\
\text { rural } \\
\text { residents } \\
\text { would } \\
\text { become more } \\
\text { versatile }\end{array}$ & $\begin{array}{l}\text { Private } \\
\text { investors or } \\
\text { farmers, } \\
\text { Zasliai } \\
\text { eldership, } \\
\text { Zasliai forestry }\end{array}$ \\
\hline & \multicolumn{3}{|c|}{ Observation of soil's condition } & Kaisiadorys \\
\hline
\end{tabular}




\begin{tabular}{|c|c|c|c|c|}
\hline & $\begin{array}{l}\text { To establish } \\
\text { association of } \\
\text { farmers of } \\
\text { Zasliai } \\
\text { eldership. In } \\
\text { cooperation } \\
\text { with } \\
\text { Kaisiadorys } \\
\text { regional } \\
\text { municipality it } \\
\text { would be } \\
\text { possible to } \\
\text { initiate the } \\
\text { examination } \\
\text { of soil's } \\
\text { condition in } \\
\text { Zasliai eldership. The } \\
\text { ordered } \\
\text { examination } \\
\text { could lead to } \\
\text { improved } \\
\text { quality of } \\
\text { grown production, } \\
\text { while the } \\
\text { association } \\
\text { could allow } \\
\text { selling production for } \\
\text { higher price }\end{array}$ & $\begin{array}{l}\text { The } \\
\text { condition of } \\
\text { soil } \\
\text { resources } \\
\text { would be } \\
\text { evaluated } \\
\text { more } \\
\text { effectively, } \\
\text { the } \\
\text { preserving } \\
\text { usage of soil } \\
\text { in agriculture } \\
\text { could be } \\
\text { induced and } \\
\text { better } \\
\text { conditions } \\
\text { for biological } \\
\text { balance of } \\
\text { the soil could } \\
\text { be created }\end{array}$ & $\begin{array}{l}\text { The } \\
\text { cooperation } \\
\text { would allow } \\
\text { carrying out } \\
\text { agrochemical } \\
\text { tests of the } \\
\text { soil for minor } \\
\text { farmers, as } \\
\text { well; besides } \\
\text { good experience } \\
\text { and insights } \\
\text { could be } \\
\text { exchanged }\end{array}$ & $\begin{array}{l}\text { regional } \\
\text { municipality, } \\
\text { farmers in } \\
\text { Zasliai } \\
\text { eldership }\end{array}$ \\
\hline \multirow{2}{*}{$\begin{array}{l}\text { Usage of } \\
\text { solar energy } \\
\text { resources to } \\
\text { generate } \\
\text { alternative } \\
\text { energy }\end{array}$} & \multicolumn{3}{|c|}{$\begin{array}{l}\text { Priority of activity of Zasliai Centre of } \\
\text { Traditional Crafts - programme of usage of } \\
\text { solar energy resources }\end{array}$} & \multirow{2}{*}{$\begin{array}{l}\text { Zasliai Centre } \\
\text { of Culture and } \\
\text { Crafts, Zasliai } \\
\text { community, } \\
\text { Kaisiadorys } \\
\text { local activity } \\
\text { group }\end{array}$} \\
\hline & $\begin{array}{l}\text { To prepare the } \\
\text { project and to } \\
\text { organize } \\
\text { seminars and } \\
\text { visits to } \\
\text { examples of } \\
\text { good practice, } \\
\text { according to the } \\
\text { practice of } \\
\text { German institute } \\
\text { "Passivhaus } \\
\text { Institut". Total }\end{array}$ & $\begin{array}{l}\text { Such an } \\
\text { initiative } \\
\text { would have } \\
\text { positive } \\
\text { impact on } \\
\text { landscape, } \\
\text { would } \\
\text { improve } \\
\text { ecological } \\
\text { conditions } \\
\text { (quality of } \\
\text { ambient air). }\end{array}$ & $\begin{array}{l}\text { The } \\
\text { educational } \\
\text { activity } \\
\text { would be } \\
\text { performed } \\
\text { through } \\
\text { organization } \\
\text { of creative } \\
\text { workshops by } \\
\text { Zasliai Craft } \\
\text { Centre, the } \\
\text { examples of }\end{array}$ & \\
\hline
\end{tabular}




\begin{tabular}{|c|c|c|c|c|}
\hline & $\begin{array}{l}\text { value of the } \\
\text { project - } 12000 \\
\text { euros; the } \\
\text { resources of the } \\
\text { EU structural } \\
\text { funds and } \\
\text { private } \\
\text { companies } \\
\text { (which could } \\
\text { promote their } \\
\text { production) } \\
\text { could be used to } \\
\text { finance the } \\
\text { project. }\end{array}$ & $\begin{array}{l}\text { This would } \\
\text { introduce } \\
\text { residents of } \\
\text { Zasliai } \\
\text { eldership to } \\
\text { advantages } \\
\text { of usage of } \\
\text { solar energy } \\
\text { and would } \\
\text { help to } \\
\text { safeguard } \\
\text { energy safety and to } \\
\text { prevent } \\
\text { conflicts }\end{array}$ & $\begin{array}{l}\text { good practice } \\
\text { would be } \\
\text { made public, } \\
\text { and seminars } \\
\text { and courses } \\
\text { about usage } \\
\text { of alternative } \\
\text { resources } \\
\text { would be } \\
\text { conducted }\end{array}$ & \\
\hline \multirow{2}{*}{$\begin{array}{l}\text { Improvement } \\
\text { of condition of } \\
\text { ambient air } \\
\text { resources }\end{array}$} & \multicolumn{3}{|c|}{$\begin{array}{l}\text { Arrangement of wind power stations around th } \\
\text { village "Zuvys" }\end{array}$} & \multirow{2}{*}{$\begin{array}{l}\text { Kaisiadorys } \\
\text { municipality, } \\
\text { owners of } \\
\text { private } \\
\text { enterprises, } \\
\text { Kaisiadorys } \\
\text { local activity } \\
\text { group }\end{array}$} \\
\hline & $\begin{array}{l}\text { To develop } \\
\text { power } \\
\text { production by } \\
\text { small wind } \\
\text { power stations } \\
\text { in Zasliai } \\
\text { eldership, } \\
\text { around the } \\
\text { village "Zuvys". } \\
\text { The majority of } \\
\text { manufacturing } \\
\text { companies } \\
\text { located in } \\
\text { Zasliai eldership } \\
\text { are in this } \\
\text { territory. They } \\
\text { may reduce } \\
\text { usage of electric } \\
\text { energy. } \\
\text { Following the } \\
\text { example of } \\
\text { good practice of } \\
\text { Smalininkai } \\
\text { community, the } \\
\text { arrangement } \\
\text { expenses of } 1 \\
\text { wind power } \\
\text { station are equal } \\
\text { to } 11050 \text { euros. }\end{array}$ & $\begin{array}{l}\text { The effective } \\
\text { usage of } \\
\text { wind energy } \\
\text { would } \\
\text { reduce air } \\
\text { pollution } \\
\text { while } \\
\text { generating } \\
\text { alternative } \\
\text { energy. }\end{array}$ & $\begin{array}{l}\text { The } \\
\text { increased } \\
\text { amount of } \\
\text { information } \\
\text { known to } \\
\text { society } \\
\text { about } \\
\text { meaning of } \\
\text { wind power } \\
\text { stations for } \\
\text { climatic } \\
\text { changes and } \\
\text { about } \\
\text { means to } \\
\text { reduce these } \\
\text { changes; } \\
\text { creation of } \\
\text { new work } \\
\text { places }\end{array}$ & \\
\hline
\end{tabular}




\begin{tabular}{|c|c|c|c|c|}
\hline \multirow{4}{*}{$\begin{array}{l}\text { Usage of water } \\
\text { and landscape } \\
\text { resources for } \\
\text { tourism and } \\
\text { recreation }\end{array}$} & \multicolumn{3}{|c|}{$\begin{array}{l}\text { Arrangement of campsite in the north eastern } \\
\text { part of the eldership, by the road Zasliai - } \\
\text { Beiciunai }\end{array}$} & \multirow{2}{*}{$\begin{array}{l}\text { Zasliai } \\
\text { community, } \\
\text { Kaisiadorys } \\
\text { regional local } \\
\text { activity group, } \\
\text { private } \\
\text { enterprises, } \\
\text { Zasliai Craft } \\
\text { Centre, local } \\
\text { residents }\end{array}$} \\
\hline & 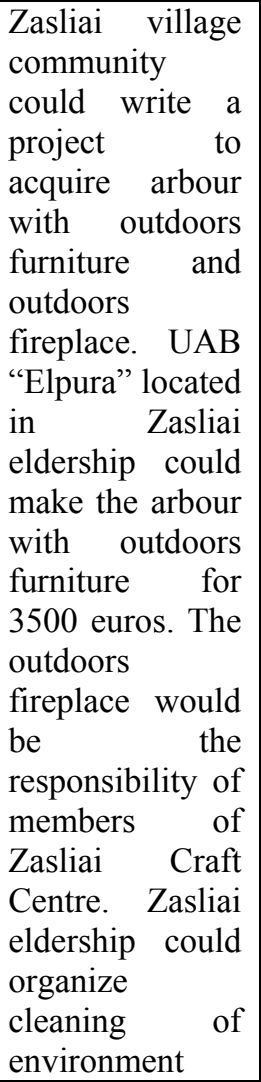 & $\begin{array}{l}\text { Tidied entry } \\
\text { to tourist } \\
\text { campsite, } \\
\text { liquidated } \\
\text { damage to } \\
\text { landscape; } \\
\text { induced wish } \\
\text { of campers to } \\
\text { maintain } \\
\text { clean } \\
\text { environment }\end{array}$ & $\begin{array}{l}\text { The } \\
\text { conditions are } \\
\text { created for } \\
\text { rest, } \\
\text { educational } \\
\text { ecological } \\
\text { tourism, and } \\
\text { full-rate rest } \\
\text { in nature. The } \\
\text { campsite } \\
\text { would be } \\
\text { easy to find } \\
\text { for travellers, } \\
\text { it would be } \\
\text { close to the } \\
\text { village centre, } \\
\text { where the } \\
\text { services } \\
\text { necessary for } \\
\text { traveller } \\
\text { would be } \\
\text { available }\end{array}$ & \\
\hline & \multicolumn{3}{|c|}{$\begin{array}{l}\text { Formation of educational walking path on the } \\
\text { coast of Zasliai lake during the workshop of } \\
\text { woodsmen }\end{array}$} & \multirow{2}{*}{$\begin{array}{l}\text { Zasliai } \\
\text { municipality, } \\
\text { Zasliai } \\
\text { community, } \\
\text { folk artists, } \\
\text { owners of } \\
\text { private forests, } \\
\text { local farmers, } \\
\text { residents }\end{array}$} \\
\hline & $\begin{array}{l}\text { The workshop } \\
\text { of woodsmen } \\
\text { could be } \\
\text { organized by } \\
\text { Zasliai } \\
\text { eldership. The } \\
\text { necessary } \\
\text { wood could be } \\
\text { given by } \\
\text { owners of } \\
\text { private forests. } \\
\text { The local } \\
\text { formers would }\end{array}$ & $\begin{array}{l}\text { When the } \\
\text { educational } \\
\text { walking } \\
\text { paths are } \\
\text { formed, the } \\
\text { society } \\
\text { would be } \\
\text { able to get } \\
\text { familiar } \\
\text { with native } \\
\text { country, } \\
\text { rare sorts of } \\
\text { plants and }\end{array}$ & $\begin{array}{l}\text { This could } \\
\text { allow } \\
\text { adjusting the } \\
\text { objects of } \\
\text { cultural } \\
\text { heritage, } \\
\text { community } \\
\text { initiatives } \\
\text { and natural } \\
\text { resources of } \\
\text { local } \\
\text { landscape } \\
\text { for the needs }\end{array}$ & \\
\hline
\end{tabular}




\begin{tabular}{|c|c|c|c|c|}
\hline & $\begin{array}{l}\text { take care about } \\
\text { transportation } \\
\text { works, while } \\
\text { the } \\
\text { volunteering } \\
\text { residents would } \\
\text { take part in } \\
\text { working bee on } \\
\text { the set day. As } \\
\text { the network of } \\
\text { sightseeing } \\
\text { objects is } \\
\text { expanded in } \\
\text { the eldership, } \\
\text { the } \\
\text { competitivenes } \\
\text { s of suggested } \\
\text { tourism } \\
\text { services would } \\
\text { increase. }\end{array}$ & animals & $\begin{array}{l}\text { of } \\
\text { educational } \\
\text { tourism. }\end{array}$ & \\
\hline \multirow[t]{2}{*}{$\begin{array}{ll}\text { Protection } & \text { of } \\
\text { resources } & \text { of } \\
\text { live nature } & \end{array}$} & \multicolumn{3}{|c|}{$\begin{array}{l}\text { Creation of information system of natural } \\
\text { objects in Zasliai, which are interesting with } \\
\text { regard to tourism }\end{array}$} & \multirow{2}{*}{$\begin{array}{l}\text { Kaisiadorys } \\
\text { local activity } \\
\text { group, } \\
\text { Kaisiadorys } \\
\text { Centre of } \\
\text { Tourism and } \\
\text { Business, } \\
\text { companies } \\
\text { providing } \\
\text { accommodatio } \\
\mathrm{n} \text { and tourism } \\
\text { services }\end{array}$} \\
\hline & 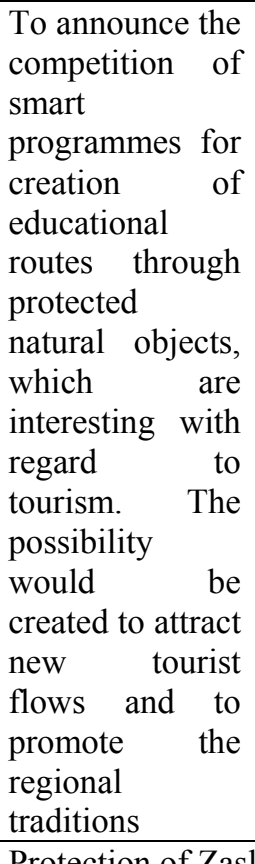 & $\begin{array}{l}\text { The mobile } \\
\text { application } \\
\text { meant for } \\
\text { residents and } \\
\text { guests of } \\
\text { Zasliai } \\
\text { eldership } \\
\text { would help } \\
\text { to get } \\
\text { familiar with } \\
\text { the protected } \\
\text { objects of } \\
\text { live nature in } \\
\text { the village }\end{array}$ & $\begin{array}{l}\text { The local } \\
\text { youth are } \\
\text { encouraged to } \\
\text { take interest } \\
\text { in potential of } \\
\text { local natural } \\
\text { resources }\end{array}$ & \\
\hline
\end{tabular}




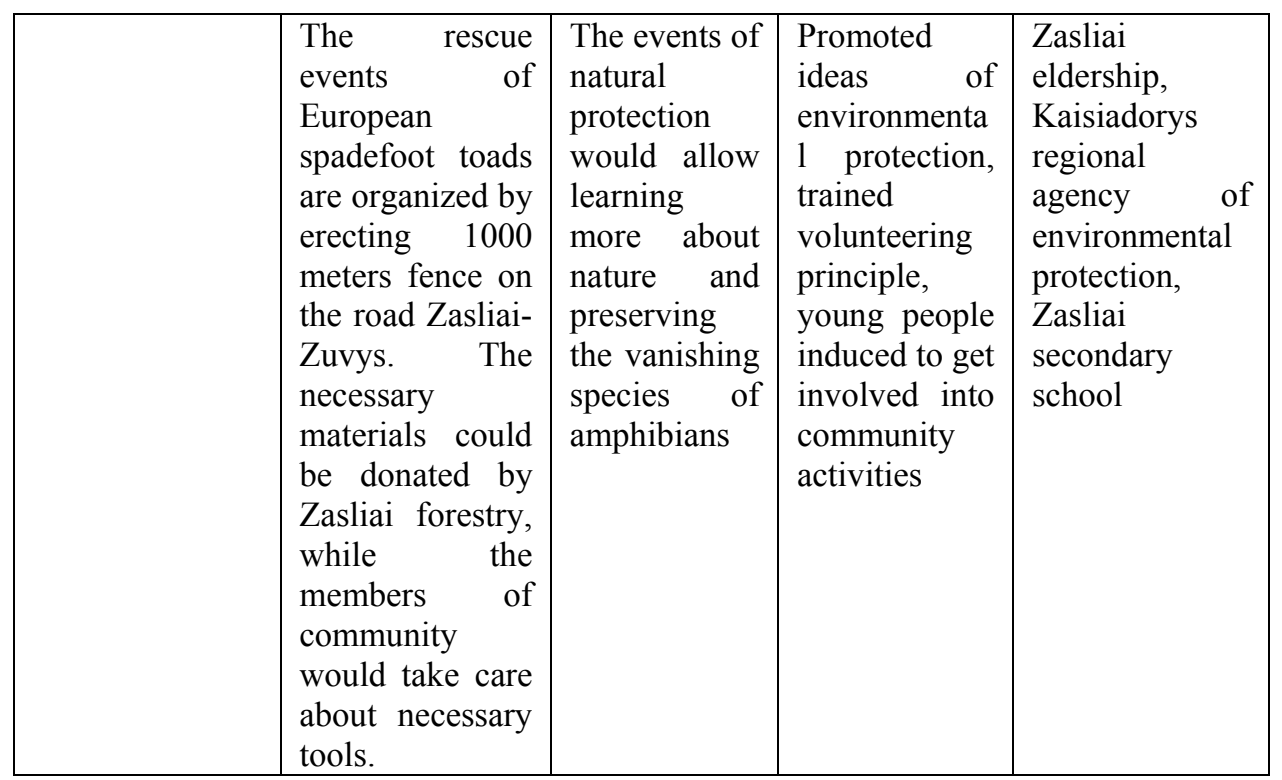

As it has been already mentioned, the landed property of various purposes occupies 68 percent of the eldership's area. Among all the land farmland, the arable takes 56,7 percent, gardens 1 percent, pastures and meadows take 23,8 percent, the roads and protection zones take 5,5 percent of the eldership's territory, and other lands - 13 percent. The majority of territories suitable for farming are improved in order to create more favourable conditions for agricultural activities. The changes of land usage planned in general plan of the eldership are based on current tendencies of development of agricultural and residential territories. Part of infertile soil or territories less favourable for farming will be planted with forest. When needed, it is planned to give land for exploitation of minerals or expansion of residential territories. This could have negative impact not only on soil, but also on water regime. Part of soil will be destroyed during constructions or exploitation of minerals in the territory of the eldership. The reduction of the area of landed property will not have significant influence on agriculture or its development. The conditions for intensive farming activity would be better in the remaining areas $f$ necessary protection means of soil are safeguarded together with balanced fertilization by organic and mineral fertilizers.

The solar energy may be used in 2 ways: to produce electric energy or heat (water heating by collectors, direct heating of buildings' partitions, etc.). The solar collectors in the eldership would be suitable to prepare hot water, i.e. the area of collectors is selected with regard to the needs of hot water. The solar collectors would allow saving expenses spent on preparation of hot water. The solar collectors would allow saving up to 70 percent of annual preparation expenses of hot water. Moreover, the solar collectors would become very topical for people, who have outdoors or indoors swimming pools. According to the data of companies, which sell systems of solar collectors (UAB "Ekoplius", 2016) the purchase of solar collector for the family of 2-4 persons costs 1500-7000 euros. 2 most popular and wide-spread systems of flat solar collectors (with 
installation) cost approx. 2300 euros. However, it is quite a big investment for the owners of private houses.

The implementation of the project "Creation of the Centre of Traditional Crafts" is coming to the end in the eldership. The centre of traditional crafts as the unit of Zasliai cultural centre is established in the premises of Zasliai cultural centre. It will provide services of preservation, teaching, consultation, etc. the programme of renewable power could also be included into the activities of the craft centre. The craft centre could contribute to the usage of potential of solar energy through organization of seminars and creative workshops. The solutions of engineering facilities would have significant positive impact on air, water and soil. When the centralized thermal supply is expanded and less pollutant fuel sorts are selected, the air quality would improve. If more users were connected to centralized water supply and wastewater networks, the quality of surface water ponds would improve.

In order to attract more tourists, it is recommended to arrange campsite in the north eastern part of the territory, by the road Zasliai-Beiciunai. The easy-to-find campsite would be close to the village centre, where the services necessary for traveller would be available. Two lakes of the village would be used for the rest by water northern part of Statkuniskis Lake would be used for beaches and Zasliai Lake would be used as the main recreation place of rest and festivals used by the residents and guests. It is recommended to arrange the recreation area with stadium and other sport courts in the northern part of Zasliai Lake, in the green area of the village. It is a territory that would be dedicated for active rest and water entertainments with the possibility to get a swim. It is suggested to arrange the place for festivals and events with the servicing structure in the cape in the western part of Zasliai Lake. The boat pier could be also arranged here. One of the biggest values is the exclusive landscape. One of the important advantages of landscape panorama is the absence of large industrial or stock-breeding buildings, silos, etc., which could cause negative impact on the environment. In order to arrange, use and protect natural framework of the territories, it is suggested to apply the following directions, which express the protection and formation types of natural landscape: the present natural character of the landscape is preserved and protected; the naturalness of landscape is maintained and increased; the elements restoring naturalness of landscape are beautified and plentified. These directions are expanded through expansion of plant arrays and belts in the valleys of streams, arrangement of recreational undeveloped areas by for rest and fun by the lakes, and through making the amount of plants bigger.

One of the possibilities to use the landscape could be formation of educational walking path on the Coast of Zasliai Lake during the workshop of woodsmen. This would not simply provide entertainment to local residents, but would also introduce the visitors with ethnographic culture of Zasliai, folk art and traditions. It is important to include natural resources present in the eldership when the idea is formed. The raw materials necessary for artistic activities would be received through cooperation with Zasliai forestry and owners of private forests. The representatives of private business, who use the quarry on the south eastern part of the lake, could contribute with machinery meant for digging and levelling. Such a creative partnership project would gather the professionals from the educational and social areas in order to improve landscape and to integrate the local natural resources. The cultural impact would be manifested through 
promotion of health and community welfare, provision of equal possibilities to create act, and participation in cultural activities.

It is important to include cultural tools used to induce health and welfare into the plan of the eldership's development. The community organizations and eldership are responsible for the project's preparation. With regard to financing, the cultural and artistic projects promoting health and welfare could be sponsored by the Ministry of Education and Culture. The cooperation with municipality, local activity groups, etc. is also important. The community's initiative could reduce the financing expenses by organizing the workshops of woodsmen.

Considering Siedlce Municipality it is worth mentioning, that the main idea for local authorities is to improve the life conditions for citizens. Thus, their interest of natural resource management become as important as the other facilities for society. Within each of the social development sphere, the natural resource management occurs.

The proposals of natural resources management improvements appear within four main activity goals:

1. Improvement of the environment quality:

○ Systematic removal of asbestos from roofs,

- Protecting the environment and improving ecological security,

$\circ$ Improving the state of the environment by introducing and enforcement of rational waste management and selective waste collection,

- Supporting measures to reduce pollutant emissions to atmosphere by households and business entities,

- Reduce the impact of traffic pollution,

- Reclamation of degraded land,

- An efficient and effective waste management system (including disposal and recycling),

- Development and modernization of integrated waste management through support

- Segregation, recycling and disposal systems, tightening of landfill and waste management controls, and the safeguarding of hazardous waste.

- Development of water retention flood retention system.

- Cooperation with the Recycling Waste Company in the field of ecological promotion.

2. The use of ecology for the development of the municipality:

- Increased use of renewable energy,

- Modernization of the citizens' boiler rooms in the scope of exchange of heating sources to modern and ecological.

- Promoting renewable energy sources (biogas, solar cells, wind farms, growing energy crops) as a source of income for agricultural holdings,

- Replacement of district heating networks with heat loss,

- Construction of new heating systems,

- Support for the use of renewable energy sources (including photovoltaics and sun collectors),

- Preparation and provision of forest areas for tourist and recreational purposes,

- Supporting forest management by shaping the ecological forest, multifunctional, providing a positive impact of the forest on the environment, 
- Thermomodernization of public buildings and collective residential buildings . 3. Modernization of local agriculture to market economy requirements:

- Supporting entrepreneurs and owners of farms in acquiring external partners (including foreign), and marketing of local products and manufacturers,

o Strengthening the institutional environment of the agricultural sector through the development of the system market information, specialist advice and training,

- Encourage the diversification of farm activities towards business nonagricultural by supporting the development of tourism, including agritourism and ecotourism,

○ Improving the efficiency of farm businesses through support modernization of equipment and buildings, improvement of agrarian structure, improvement of production quality and diversification of directions of agricultural production (biofuels, renewable energy, etc.),

- Development of the offer and improvement of the availability of support instruments for ecological development agriculture and food processing and marketing of high quality food products,

- To initiate the formation, support and promotion of various organizations of association farmers,

- Support and promotion of the creation of agritourism farms and production of healthy food,

- Help with the organization of local product sales locations,

- Encourage farmers to acquire specialized knowledge about modern methods of agricultural production and requirements in force in the European Union.

To summarize, it is possible to note that the suggestions, how to improve resources' management and how to include them into the local government activities , could look to development priorities and projects under preparation more rationally and in more complex way. They should be organized in attempt to achieve sustainable rural and social development through management of natural resources. It is relevant that the suggested practical recommendations are actually possible to implement if the facilities useful for social needs are created and the natural resources present in the eldership are used.

\section{Conclusions}

1. The analysis of natural resources allowed determining the following: the lands in the eldership are tamed, which has negative impact on soil resources; the solar energy resources are used little or ineffectively; private transport worsens quality of ambient air; water quality of the lakes is good, but there is lack of localities adjusted for recreation and tourism, which would attract more tourists; and protection of live nature is safeguarded.

2. Planting of less fertile soils with forest and observation of the soil's condition would contribute to improvement of quality of ambient air, would have positive impact on the local landscape, and would improve ecologic conditions.

3. The sustainable development of the eldership based on the usage of renewable energy sources could serve as effective means to create complex usage of wind and sun 
resources available in the locality, which would cover not only production of energy, but also its supply and usage.

4. The purposeful usage of water and landscape resources would contribute to sustainable expansion of approaches to Zasliai Lake by adjusting them for recreation and rest. The territory's adjustment for sport needs would help to attract bigger flows of local society and visitors, who would also use other services provided by Zasliai Lake (accommodation, feeding, etc.).

5. The natural resource management in Siedlce Municipality is a part of the Strategy of Development, which stresses the role of social development. Within the aims to fulfil, the natural resources management are reduced to saving the natural environment, protecting it and to introduce the ecology to citizens.

\section{References}

ALEKSANDRAVIČIUS, A.; ŽUKOVSKIS, J. 2011. Kaimo bendruomenių raida ir jų veiklos tikslai: siekiant darnumo visuomenėje [interaktyvus], [žiūrèta 2016 m. gegužès 05 d.]. Prieiga per internetą: < http://etalpykla.lituanistikadb.lt/fedora/objects/LT-LDB-

0001:J.04 2011 1367168789998/datastreams/DS.002.0.01.ARTIC/content >;

BALEŽENTIS, A. 2011. Kaimo vietovių raida ir modeliai: darnaus vystymo požiūris [interaktyvus], [žiūrèta 2016 m. kovo 19 d.]. Prieiga per internetą: < http://vadyba.asu.lt/26/31.pdf >;

BENOIT, R.: CHARLES, C. 2012. Configurational Comparative Methods Qualitative Comparative Analysis [interaktyvus], [žiūrèta 2016 m. gegužès 10 d.]. Prieiga per internetą: <http://goo.gl/6gY9Qg>;

BUKANTIS, A.; GEDŽIŪNAS, P. IR KT. 2008. Lietuvos gamtinè aplinka, būklè, procesai ir raida [interaktyvus], [žiūrèta $2016 \mathrm{~m}$. balandžio 24 d.]. Prieiga per internetą:

$<$ http://193.219.133.6/aaa/pranesimai/Lietuvos_gamtine_aplinka_bukle_procesai_ir_raida.pdf $>$.

Burchart-Korol D., zrównoważone zarządzanie zasobami naturalnymi bazując na gospodarce cyrkulacyjnej,

Zeszyty Naukowe Politechniki Śląskiej, Seria: Organizacja i Zarządanie, Z.87, 2016

DARGUŽAS, A. 2011. Interesų konfliktas sprendžiant klimato kaitos problemą, jų mažinimas. [interaktyvus], [žiūrėta $2016 \mathrm{~m}$. balandžio 14 d.]. Prieiga per internetą: http://vddb.library.lt/fedora/get/LT-eLABa0001:E.02 2011 D_20110705_131620-62024/DS.005.0.01.ETD

GRANT, M. 2010. Contemporary Strategy Analysis and Cases [interaktyvus], [žiūrèta 2016 m. gegužès 5 d.]. Prieiga per internetą:

http://books.google.lt/books?hl=lt\&lr=\&id=dXw6MkTCbeoC\&oi=fnd\&pg=PA209\&dq=grant + rm $+.+2010+$ co ntemporary+strategy+analysis\&ots $=8 \mathrm{gnBFECEZ} \&$ sig $=$ grfVztP9Kd6T2w8Cx8RObzsjCTY\&redir_esc $=\mathrm{y} \# \mathrm{v}=$ onepage \&q=grant $\% 20 \mathrm{rm} \% 20 . \% 202010 \% 20$ contemporary $\% 20$ strategy $\% 20$ analysis $\& \mathrm{f}=$ false $>$.

GRUNDEY, D. 2012. Managing sustainable tourism in Lithuania: Dream or reality? [interaktyvus], [žiūrèta

2016 m. balandžio 17 d.]. Prieiga per internetą: <http://www.tandfonline.com/doi/pdf/10.3846/13928619.2008.14.118-129>

HERRIGES, JA.; KLING, CL. 2012. The Measurement of Environmental and Resource Values - Theory and Methods [interaktyvus], [žiūrèta 2016 m. gegužès 3 d.]. Prieiga per internetą: <

http://www.routledge.com/books/details/9780415501583/>.

KISIELIENĖ, G. 2012. Gamtinių išteklių, kraštovaizdžio ir bioịvairovès apsauga. Kaunas: Technologija.

KRANKALIS, R.; ANZELYTĖ, R. 2013. Darnaus vystymosi nuostatų igyvendinimas kaimiškosiose

savivaldybėse. [interaktyvus], [žiūrèta $2016 \mathrm{~m}$. balandžio 24 d.]. Prieiga per internetą:

$<$ http://vddb.library.lt/fedora/get/LT-eLABa-0001:J.04 2013 ISSN_2029-8846.N_1_5.PG_40-

52/DS.002.0.01.ARTIC >

Lietuvos Respublikos aplinkos ministerija. 2001. Rio deklaracija: apie aplinką ir plètrą [interaktyvus], [žiūrèta 2016 m. gegužès 12 d.]. Prieiga per internetą: < http://www.am.lt/LSP/files/Agenda21.pdf >;

Lietuvos Respublikos teritorijos bendrasis planas. [interaktyvus], [žiūrèta $2016 \mathrm{~m}$. balandžio 20 d.]. Prieiga per internetą: http://www3.1rs.lt/pls/inter2/dokpaieska.showdoc_1?p_id=284909>;

Lietuvos Respublikos regioninès plètros įstatymas [interaktyvus], [žiūrèta $2015 \mathrm{~m}$. balandžio $20 \mathrm{~d}$.]. Prieiga per internetą: http://www3.lrs.lt/pls/inter3/dokpaieska.showdoc_1?p_id=298580 
LYNAM, T.; NORFOLK, S. 2013. Review of Tools for Incorporating Community Knowledge, Preferences, and Values into Decision Making in Natural Resources Management [interaktyvus], [žiūrèta 2015 m. gegužès 11 d.]. Prieiga per internetą: <http://www.mtnforum.org/sites/default/files/publication/files/1730.pdf>;

MONT, O; BLEISCHWITZ, R. 2012. Sustainable Consumption and Resource Management in the Light of Life Cycle Thinking [interaktyvus], [žiūrèta 2016 m. balandžio 23 d.]. Prieiga per internetą:

$<$ http://www.researchgate.net/profile/Raimund_Bleischwitz/publication/229588688_Sustainable_consumption _and_resource_management_in_the_light_of_life_cycle_thinking/links/54045e2focf $23 \mathrm{~d} 9765 \mathrm{a} 62369$.pdf $>$.

„Pažangių technologijų ir gerosios praktikos žemés ūkyje taikymas bei skatinimo Lietuvoje, siekiant išvengti aplinkos taršos iš žemès ūkio šaltinių, studija“ " [interaktyvus], [žiūrèta $2016 \mathrm{~m}$. balandžio 20 d.]. Prieiga per internetą: http://www.zum.lt/zum/m/m_files/wfiles/file1879.pdf

SKURDENIENĖ, I.; ŠEŠKAUSKAITE், D. 2010. Lyderių vaidmuo Lietuvos kaime: ekonominio išsivystymo ir lyčių lygybès aspektai [interaktyvus], [žiūrèta 2016 m. gegužès 4 d.]. Prieiga per internetą: < http://vddb.library.lt/fedora/get/LT-eLABa-0001:J.04 2010 ISSN_1648-9098.N_3_2_19.PG_39-

48/DS.002.0.01.ARTIC $>$.

SZUFLICKI M., MALON A. TYMIŃSKI M., Bilans zasobów złóż kopalin w Polsce, Państwowy Instytut Geologiczny, Państwowy Instytut Badawczy, Warszawa 2016

Strategia Rozwoju Gminy Siedlce na lata 2016-2026, Załącznik do Uchwały Nr XVIII/138/2015 Rady Gminy Siedlce z dnia 29 grudnia 2015 roku

Informacja o autorach:

dr Anna Świrska

Siedlce University of Natural Sciences and Humanities, Poland

Faculty of Economic and Legal Sciences

e-mail: annaswirska@gmail.com

Lina Marcinkevičiūtè, Jan Žukovskis,

Aleksandras Stulginskis University, Lithuania

e-mail: Lina.Marcinkeviciute@asu.lt; Jan.Zukovskis@asu.lt 